\title{
Larvicidal potentials of selected plants against Culex quinquefasciatus (Say, 1823) (Diptera: Culicidae) in Owerri Imo State, Nigeria
}

\author{
*Amaechi Austin., Uzoagba Deborah and Nwoke Bethram \\ Corresponding Author E-mail: amaechiaustine@ymail.com \\ DOI: $10.31364 / \mathrm{SCIRJ} / \mathrm{v} 7.19 .2019 . P 0919718$ \\ http://dx.doi.org/10.31364/SCIRJ/v7.i9.2019.P0919718
}

Medical Entomology Unit, Department of Animal and Environmental Biology, Imo State University Owerri, Nigeria

\begin{abstract}
During the last decades lot of studies on natural plants as larvicides against mosquitoes has indicated positive results and can be used as alternatives against pesticides. The present study is focused on natural plants with insecticidal properties for control of Culex quinquefasciatus. Aqueous, methanol and Acetone were evaluated against the $4^{\text {th }}$ instar larvae of C. quinquefasciatus, an important filariasis vector. Phytochemical screening of the plants showed the presence of phyto compounds such as tannins, alkaloids, flavonoids, saponins, steroids, Quinones, Phenols and Glycosids. Different concentrations (10\%-60\%) of the extraction were used. Mortality of the larvae was observed within $24 \mathrm{hrs}$ of exposure. Results showed that higher extracts concentrations were greater in efficacy as compared to lower concentrations. It is concluded that all the 6 species of plants and parts used can be used for the prevention and control of $C$. quinquefasciatus mosquito due to there pesticide properties and bioactive chemicals and can be considered for further investigations.
\end{abstract}

Keywords: plant extracts, phytochemicals, larvicidal activity, Culex quinquefasciatus, mortality

\section{Introduction}

Mosquitoes are major public problem throughout the world. They are the most important blood sucking arthropods. They not only cause nuisance to humans by biting but also transmit diseases with many socioeconomic consequences. The situations has worsen due to climatic changes. This combined with other factors has favoured mosquitoes to adapt to a wide range of habitats and thereby increase their population (Michaelakis et al., 2009). Several mosquito genera; Aedes, Anopheles, Culex and Mansonia are vectors for many pathogenic organisms causing human diseases (filariasis, malaria, Dengue fever etc).

Use of chemical insecticides is one of the widely used control approach. Mosquitoes have developed resistance against these commercial chemicals use as insecticides (Watal et al., 1981). These set of chemicals greatly affect the living beings and environment as well. There is an imperative demand to search novel eco-friendly substances which are much active and cost effective than the synthetic insecticides. Plants have a great diversity of naturally occurring biologically potent chemicals that can be used as larvicidal agents due to biochemical with wide range activities and safe on environments (Sukumar et al 1991).

Recently focus on plant research has increased all over the world and a large body of evidence has collected to show immense potentials for controlling insects. Plants have secondary metabolites considered potential alternative approach against different species of mosquitoes and stages due to richness in bioactive compounds, easy availability, environmental safety etc (Mohan et al 2012; Butt et al 2016; Rathy et al 2014). As part of continued search for plant extracts with larvicidal properties, the activity of plant extracts of 6 
plants were worked out in the present study against larvae of Culex quinquefasciatus through larvicidal bioassay. The findings of the study will be useful in promoting research on control of mosquitoes with indigenous plant sources.

\section{Materials and methods}

\subsection{Selection of mosquitoes and Culture}

Artificial breeding was done. At the collection site, abandoned tire and containers were placed carefully close to the opening of the septic tanks. These contain water mixed with small piece of turf. This is necessary to make the water mimic the septic tank water so that it may serve as potential breeding site (plates 1 and 2). The setup was under constant observation. Oviposition was noticed after two days.

After hatching, a sustainable amount of first instar larvae were collected by dipping a standard dipper (a scoop of $10 \mathrm{~cm}$ in diameter and $7 \mathrm{~cm}$ deep). From the second day onwards the larvae were fed twice a day on mixture of bread, powdered milk and yeast crushed together in the proportion of 1:1:1 by weight. The food was sprinkled onto the surface in small amounts enough for all to be taken in order not to foul the water. The water of the dish was changed at least twice a week. Dead larvae were removed as soon as discovered. The temperature of the dish water ranged between 21 and $27^{\circ} \mathrm{C}$. To minimize heterogeneity among the population used. In all cases only healthy late third or early fourth instar larvae were used.

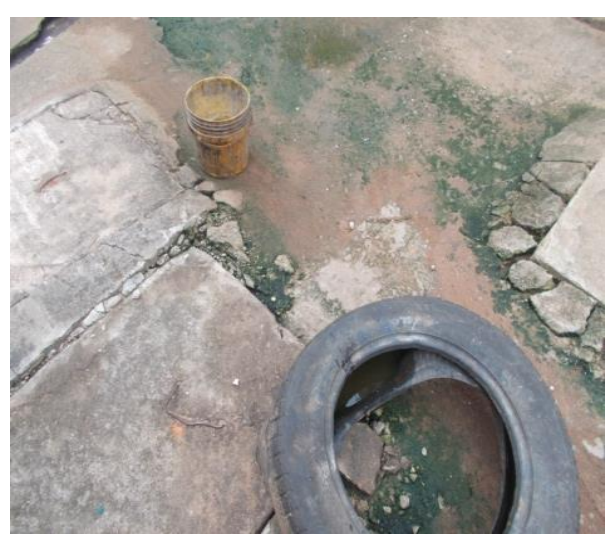

Plate 1: Larvae collection site at

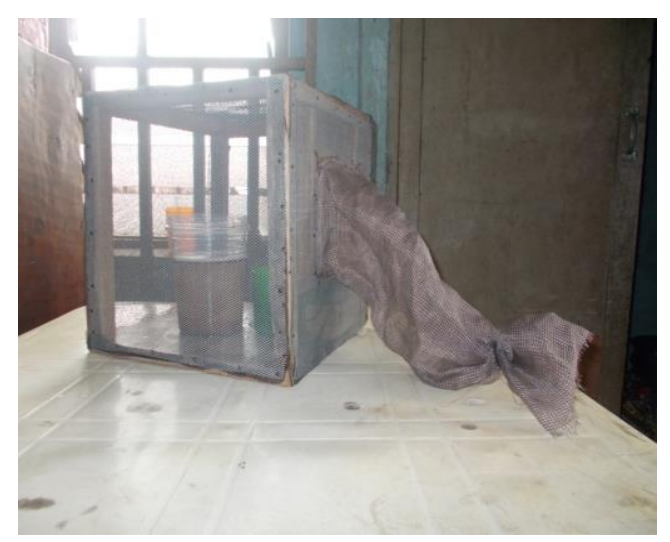

Plate 2: Mosquito rearing cage

Emmanuel college. Layout

\subsection{Collection of plants, identification and Authentication}

Selected parts of the plants (plates 3-8) were harvested during the study period. This was done in the early morning hours, as recommended by Vinavagam et. al., (2008). They were collected locally from farm lands of neighbouring communities (Nekede, Ihiagwa and ADP center, Ministry of Agriculture Owerri Imo State.).

The plants were first identified at the Agriculture Development research Department of Imo State Ministry of Agriculture. Afterwards, portions of the plants were sent to Dr. AS Amadi of Plant and Science Laboratory University of Nigeria Nsukka, for authentication. These were then transported to the Phytochemistry Department of the National Arbovirus and Vector Resaesch center Enugu, for analysis to establish the presense of active ingredients. 


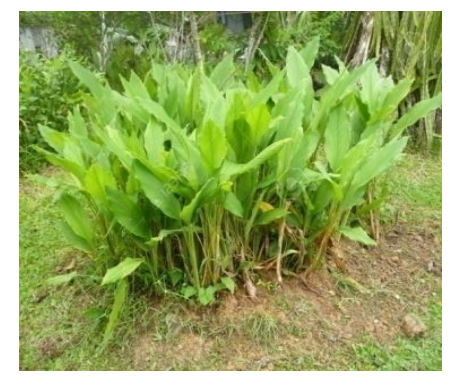

Plate 3- Cucuma longa (Turmeric)

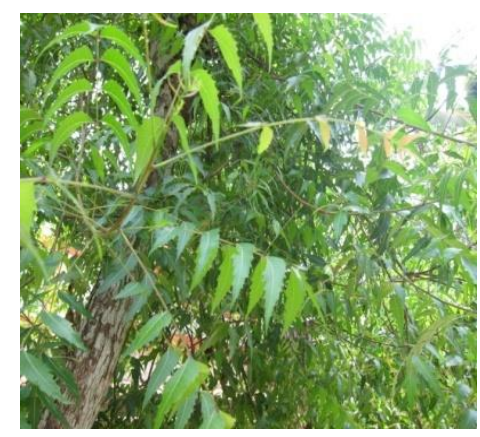

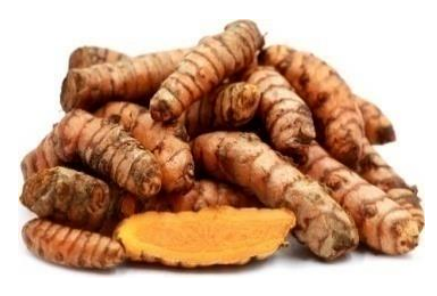

The Root

Plate 4- Azadirachta indica (Neem). The leaves
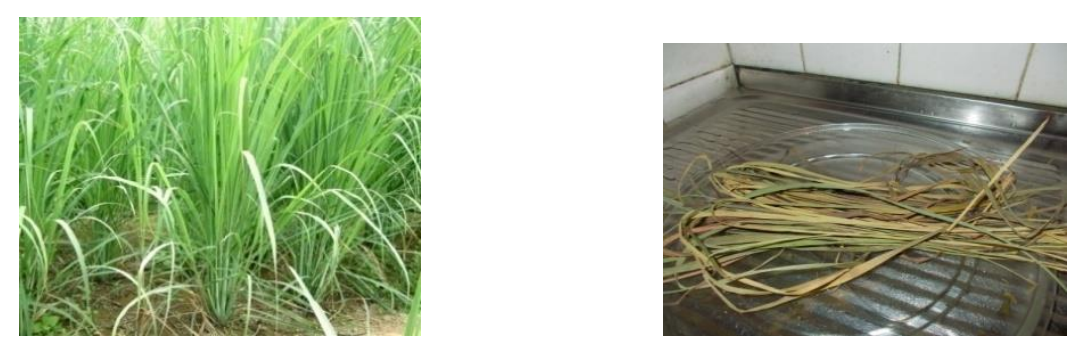

Plate 5- Cymbopogon citrates (Lemon grass). The leaves
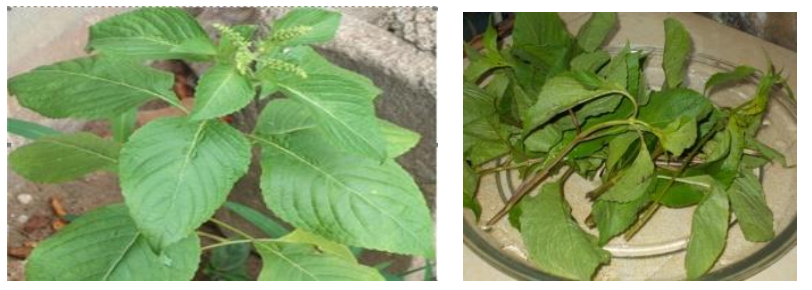

Plate 6- Ocimum gratisum (Scent leaves) 

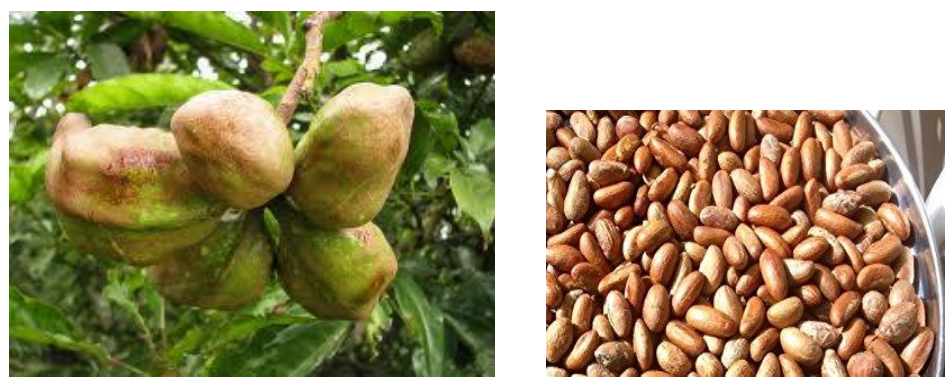

Plate 7- Garicinia cola (Bitter cola) The Seed

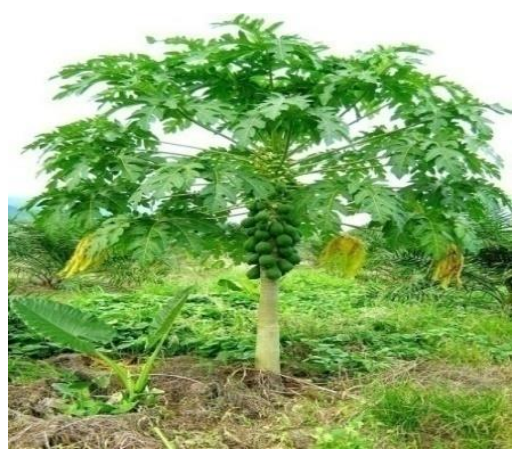

Plate 8- Carica papaya (Pawpaw)
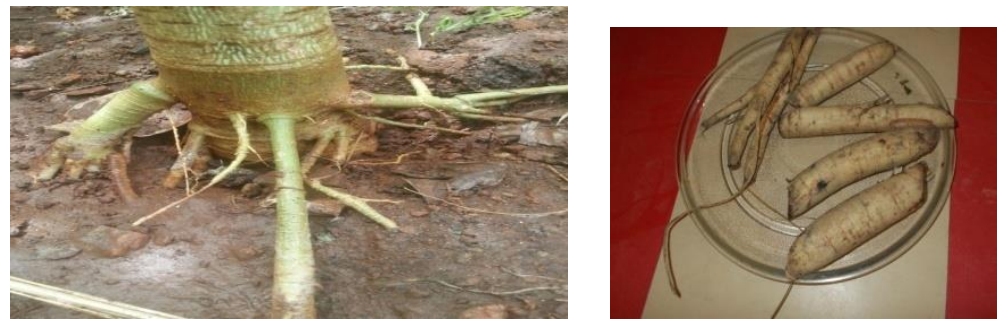

The Root

\subsection{Extraction Process}

All the plants were initially rinsed with distilled water, dried on a paper towel, and then air dried at normal room temperature $24^{\circ} \mathrm{C}$ $28^{\circ} \mathrm{C}$; some of the plants were able to dry within 10-18 days (Neem, Scent leaf \& Lemon grass). Others (paw paw root) dried within 21 days. Bitter kola and Turmeric was shred to small piece using grater before drying. After drying, all the samples were ground. The grinding process was done using both manual and electric grinder.

\subsubsection{Preparation of Extract}

Soxhlet apparatus and cold process was used to extract the active principles. Both the aqueous, methanol and acetone extract were prepared. Removing of excess solvents from the extracts (concentration) was done using rotary evaporator and water bath at $50^{\circ} \mathrm{c}$. Physical parameter of the extracts such as color, relative density, solidification point, specific gravity, refractive index, density, relative density was noted.

\subsubsection{Water extraction:}

$150 \mathrm{~g}$ of the ground materials was dissolved in $200 \mathrm{ml}$ of distilled water. The bland was centrifuged at 300rpm for 15 minutes. The supernatant was collected by filtration through a filter paper. Required concentrations of aqueous were then prepared by mixing the crude/stock with a suitable amount of sterilized distilled water. (Sofowara, 1993, Ankit, et. al., 2012)

\subsubsection{Methanolic and Acetonic extracts}

The Methanolic and Acetonic extracts $150 \mathrm{~g}$ of each of the six plant materials were collected, dried in the oven at $70^{\circ} \mathrm{C}$ for $4 \mathrm{~h}$ and reduced to powder. It was separately macerated with the above solvents and allowed to stand for $72 \mathrm{hrs}$ and then filtered. The filtrates 
were then evaporated under reduced pressure and dried using a rotary evaporator at 50 - $55^{\circ} \mathrm{C}$. (Sofowara, 1993 , Kaufmann and Christen, 2002.)

\subsection{Phytochemical analysis}

Chemical tests for the screening and identification of bioactive chemical constituents in the plants under study were carried out in extracts of specimens using the standard procedures (Hurbune, 1984).

\subsection{Larvicidal Bioassay:}

Larval form of the mosquito species was separately introduced into different petri dishes containing graded concentrations of the plant extracts. Five replicates of each concentration were performed, with one standing as control. The number of mortality records was taken after every one hours of the 24 hours exposure period. The process of the larvicidal bioassay followed the World Health Organization standard protocols (WHO 2005).

\subsection{Percentage mortality of larvae mortality of the larvae was checked within $24 \mathrm{hrs}$.}

Mortality rate $=$ no of total tested larvae - no of dead larvae/no of total larvae x 100

\subsection{Statistical Analysis}

The results were analysed using the MiniTAB vetrsion 16 statistical package.

\section{RESULTS}

Details of plants used for the present study are shown in table 1. The results of phytochemical characteristics are presented in Table 2. The preliminary screening showed the strong presence of Saponin, Quinone, Glycosid, Flavonoid in aqueous, methanol and Acetone extracts. The other phytochemicals present were Tanin, Phenol and Steroid (Table 2). Probit analysis between the concentrations of plant extracts against C. quinquefasciatus within $24 \mathrm{hrs}$ exposure are represented in tables 3-8. It is evident from Table 3 that six different concentrations of Tumeric extract concentrations used were effective against the larval stages of Culex quinquefasciatus mosquitoes except the 1st concentration. In all concentrations the mortality was time and dose dependent. The result further show that each of the concentration recorded higher rate of mortality during $21-24^{\text {th }}$. The time of action varies for each of the mortality recorded differed in the different concentrations $(\mathrm{P}<0.05)$. All the six different concentrations used were effective against the larval stages of Culex quinquefasciatus mosquito (Table 4). Each of the concentration recorded higher rate of mortality during 21-24 ${ }^{\text {th }}$ hour except the $1^{\text {st }}$ concentration that recorded $40 \%$ mortality rate for $16-21^{\text {st }}$ hour $24^{\text {th }}$ hour respectively. The $3^{\text {rd }}$ concentration recorded $60 \%$ mortality rate was or $16-21^{\text {st }}$ hour and $21-24^{\text {th }}$ hour respectively. In all concentrations of extracts the mortality was time and dose dependent.

Table 5 showed that six different concentrations of Lemon grass extract used, were effective against the larval stages of Culex quinquefasciatus mosquito. In all concentrations, mortality was time and dose dependent. Concentrations 1 and 4, recorded a mortality case only in $21-24^{\text {th }}$ hour for concentration 1 and $16-20^{\text {th }}, 21-24^{\text {th }}$ hour for concentration 4 . The result also showed that there were more mortality case recorded between the 21-24th hour duration except for concentration 2 and 3 were 16-20th hour and 21-24th hour had the same mortality rate (Table 5). The result in Table 6 has showed that all the six different concentrations of Scent leaf extract used, were effective against the larval stages of Culex quinquefasciatus mosquito. Low mortality rates were recorded except 
for the 1st concentration with no mortality recorded. In all the concentrations, mortality was time and dose dependent. The duration 21-24th hour had more mortality. The result in Table 7 has show that the six different concentrations of $G$. cola extract used, were effective against the larval stages of Culex mosquito. Low mortality rate were recorded but the $1^{\text {st }}$ and $2^{\text {nd }}$ concentration had no mortality rates. In all concentrations of extracts the mortality was time and dose dependent. The duration of $16-20^{\text {th }}$ and $21-24^{\text {th }}$ hour had more mortality rates. It is evident from Table 8 that all the six different concentrations of pawpaw root extract used, were effective against the larval stages of Culex mosquito. In all concentrations of extracts the mortality was time and dose dependent. The result also showed that each of the concentration recorded higher rate of mortality during $21-24^{\text {th }}$ hour.

Table 1: List of selected local Plants used for the preparation of extracts.

\begin{tabular}{llll}
\hline S/n & Common names & Botanical names & Part used \\
1 & Tumeric & Cucuma longa & Root \\
2 & Neem/Dongoyaro/Ochonyeogwo & Azadirachta indica & Leaves \\
3 & Lemon grass & Cymbopogon citrates & Leaves \\
4 & Scent leaves/Nchuanwu & Ocimum gratisium & Leaves \\
5 & Bitter cola & Garinna kola & Seed \\
6 & Pawpaw & Carica papaya & Root \\
\hline
\end{tabular}

Table 2: Phytochemical screening of Plant extract

\begin{tabular}{|c|c|c|c|c|c|c|c|c|c|}
\hline $\mathbf{S} / \mathbf{N}$ & Plant species & Alkaloid & Saponin & Quinone & Flavonoid & Tannin & Phenol & Steroid & Glycosid \\
\hline \multicolumn{10}{|c|}{ Aqueous Extract } \\
\hline 1 & $C$, longa & +++ & ++ & ++ & ++ & ++ & +++ & +++ & +++ \\
\hline 2 & A. Indica & ++ & +++ & +++ & +++ & +++ & +++ & +++ & ++ \\
\hline 3 & C. citrate & +++ & +++ & +++ & ++ & ++ & ++ & +++ & +++ \\
\hline 4 & O. gratisum & ++ & +++ & +++ & +++ & +++ & + & + & ++ \\
\hline 5 & G. cola & +++ & ++ & +++ & +++ & + & + & + & ++ \\
\hline 6 & C. papaya & +++ & +++ & +++ & +++ & +++ & +++ & +++ & ++ \\
\hline \multicolumn{10}{|c|}{ Methanol Extract } \\
\hline 1 & C. longa & + & +++ & + & - & - & + & +++ & +++ \\
\hline 2 & A. Indica & + & + & + & + & + & - & + & +++ \\
\hline 3 & C. citrate & + & ++ & ++ & - & ++ & + & + & + \\
\hline 4 & O. gratisum & + & +++ & + & + & +++ & + & + & +++ \\
\hline 5 & G. cola & + & +++ & + & + & +++ & + & + & +++ \\
\hline${ }^{6}$ Ace & $\begin{array}{l}\text { C. papaya } \\
\text { ne Extract }\end{array}$ & +++ & ++ & +++ & ++ & ++ & ++ & + & + \\
\hline 1 & $C$, longa & +++ & + & +++ & - & - & ++ & +++ & _- \\
\hline 2 & A. Indica & ++ & + & +++ & ++ & ++ & - & + & - \\
\hline 3 & C. citrate & + & ++ & ++ & ++ & - & - & ++ & + \\
\hline 4 & O. gratisum & + & + & + & +++ & - & + & + & + \\
\hline 5 & G. cola & +++ & +++ & ++ & +++ & + & + & ++ & + \\
\hline 6 & C. papaya & +++ & ++ & + & +++ & _ & _ & +++ & + \\
\hline
\end{tabular}




\section{Key interpretations of results}

+ indicates low

+ indicates moderate

+++ indicates high 
Table 3: Mortality among Culex quinquefasciatus Larvae treated with different concentrations of Tumeric extract

\begin{tabular}{|c|c|c|c|c|c|c|c|c|c|c|c|c|c|c|c|}
\hline \multirow[b]{2}{*}{$\mathbf{S} / \mathbf{N}$} & $\operatorname{Concn}(\%)$ & \multirow{2}{*}{$\begin{array}{l}\text { No of } \\
\text { Larvae }\end{array}$} & \multicolumn{5}{|c|}{ No of mortality/Period of exposure (hr) } & \multirow[b]{2}{*}{$(\%)$} & \multirow[b]{2}{*}{$16-20(4)$} & \multirow[b]{2}{*}{$(\%)$} & \multirow[b]{2}{*}{$21-24(5)$} & \multirow[b]{2}{*}{$(\%)$} & \multirow[b]{2}{*}{ Mean } & \multirow[b]{2}{*}{$\begin{array}{l}\text { Std. } \\
\text { Dev. }\end{array}$} & \multirow[b]{2}{*}{ Ranking } \\
\hline & $\begin{array}{l}\text { of Tumeric } \\
\text { extract }\end{array}$ & & $\leq 5(1)^{*}$ & $(\%)$ & 6-10 (2) & $(\%)$ & $11-15(3)$ & & & & & & & & \\
\hline 1 & 10 & 20 & 1 & 5 & 1 & 5 & 1 & 5 & 1 & 5 & 1 & 5 & 1 & 0 & $6^{\text {th }}$ \\
\hline 2 & 20 & 20 & 2 & 10 & 3 & 15 & 3 & 15 & 4 & 20 & 6 & 30 & 4 & 1.4 & $5^{\text {th }}$ \\
\hline 3 & 30 & 20 & 1 & 5 & 4 & 20 & 5 & 25 & 6 & 30 & 8 & 40 & 5 & 2.3 & $4^{\text {th }}$ \\
\hline 4 & 40 & 20 & 1 & 5 & 5 & 25 & 6 & 30 & 7 & 35 & 9 & 45 & 6 & 2.7 & $3^{\mathrm{rd}}$ \\
\hline 5 & 50 & 20 & 0 & 0 & 5 & 25 & 7 & 35 & 8 & 40 & 9 & 45 & 6 & 3.2 & $2^{\text {nd }}$ \\
\hline 6 & 60 & 20 & 1 & 5 & 6 & 30 & 10 & 50 & 13 & 65 & 17 & 85 & 9 & 5.5 & $1^{\mathrm{st}}$ \\
\hline
\end{tabular}


Table 4: Mortality among Culex quinquefasciatus Larvae treated with different concentrations of Neem extract

\begin{tabular}{|c|c|c|c|c|c|c|c|c|c|c|c|c|c|c|c|}
\hline \multirow{3}{*}{$\begin{array}{l}\mathbf{S} / \mathbf{N} \\
1\end{array}$} & \multirow{2}{*}{$\begin{array}{l}\text { Conc(\%) } \\
\text { of Neem } \\
\text { extract }\end{array}$} & \multicolumn{11}{|c|}{ No of mortality/Period of exposure (hr) } & \multirow[b]{2}{*}{ Mean } & \multirow{3}{*}{$\begin{array}{l}\text { Std. } \\
\text { Dev. } \\
4.0988\end{array}$} & \multirow{3}{*}{$\begin{array}{l}\text { Ranking } \\
\text { Least }\end{array}$} \\
\hline & & \multirow{2}{*}{$\begin{array}{l}\begin{array}{l}\text { No of } \\
\text { Larvae }\end{array} \\
20\end{array}$} & \multicolumn{2}{|c|}{$\begin{array}{l}\leq 5 \\
(1)(\%)\end{array}$} & \multicolumn{2}{|c|}{$\begin{array}{l}6-10 \\
(2)(\%)\end{array}$} & \multicolumn{2}{|c|}{$\begin{array}{l}11-15 \\
(3)(\%)\end{array}$} & \multicolumn{2}{|c|}{$\begin{array}{l}16-20 \\
(4)(\%)\end{array}$} & \multicolumn{2}{|c|}{$\begin{array}{l}21-24 \\
(5)(\%)\end{array}$} & & & \\
\hline & 10 & & 0 & 0 & 0 & 0 & 2 & 10 & 8 & 40 & 8 & 40 & 3.6 & & \\
\hline 2 & 20 & 20 & 1 & 5 & 6 & 30 & 9 & 45 & 10 & 50 & 11 & 55 & 7.4 & 3.6111 & $4^{\text {th }}$ \\
\hline 3 & 30 & 20 & 1 & 5 & 6 & 30 & 8 & 40 & 12 & 60 & 12 & 60 & 7.8 & 4.1183 & $3^{\text {rd }}$ \\
\hline 4 & 40 & 20 & 2 & 10 & 3 & 15 & 8 & 40 & 11 & 55 & 13 & 65 & 7.4 & 4.3174 & $4^{\text {th }}$ \\
\hline 5 & 50 & 20 & 2 & 10 & 8 & 40 & 9 & 45 & 9 & 45 & 12 & 60 & 8 & 3.2863 & $2^{\text {nd }}$ \\
\hline 6 & 60 & 20 & 3 & 15 & 9 & 45 & 10 & 50 & 11 & 55 & 12 & 60 & 9 & 3.1623 & $1^{\mathrm{st}}$ \\
\hline
\end{tabular}

Table 5: Mortality among Culex sp. Larvae treated with different concentrations of Lemon grass extract

\begin{tabular}{|c|c|c|c|c|c|c|c|c|c|c|c|c|c|c|c|}
\hline \multirow{3}{*}{$\begin{array}{l}\mathbf{S} / \mathbf{N} \\
1\end{array}$} & \multirow{3}{*}{$\begin{array}{l}\text { Concn(\%) } \\
\text { of Lemon } \\
\text { grass } \\
\text { extract } \\
10\end{array}$} & \multicolumn{13}{|c|}{ No of mortality/Period of exposure (hr) } & \multirow{3}{*}{$\begin{array}{l}\text { Ranking } \\
\text { Least }\end{array}$} \\
\hline & & \multicolumn{3}{|c|}{$\begin{array}{l}\text { No of } \leq 5 \\
\text { Larvae (1) }(\%)\end{array}$} & \multicolumn{2}{|c|}{$\begin{array}{l}6-10 \\
(2)(\%)\end{array}$} & \multicolumn{2}{|c|}{$\begin{array}{l}11-15 \\
\text { (3) }(\%)\end{array}$} & \multicolumn{2}{|c|}{$\begin{array}{l}16-20 \\
(4)(\%)\end{array}$} & \multicolumn{2}{|c|}{$\begin{array}{l}21-24 \\
(5)(\%)\end{array}$} & \multirow{2}{*}{$\begin{array}{l}\text { Mean } \\
0.4\end{array}$} & \multirow{2}{*}{$\begin{array}{l}\text { Std. } \\
\text { Dev. }\end{array}$} & \\
\hline & & 20 & 0 & 0 & 0 & 0 & 0 & 0 & 0 & 0 & 2 & 10 & & & \\
\hline 2 & 20 & 20 & 1 & 5 & 1 & 5 & 0 & 0 & 2 & 10 & 2 & 10 & 1.2 & 0.748 & $2^{\text {nd }}$ \\
\hline 3 & 30 & 20 & 0 & 0 & 0 & 0 & 1 & 5 & 2 & 10 & 2 & 10 & 1 & 0.894 & $3^{\text {rd }}$ \\
\hline 4 & 40 & 20 & 0 & 0 & 0 & 0 & 0 & 0 & 1 & 5 & 2 & 10 & 0.6 & 0.8 & $4^{\text {th }}$ \\
\hline 5 & 50 & 20 & 1 & 5 & 1 & 5 & 1 & 5 & 2 & 10 & 3 & 15 & 1.6 & 0.8 & $1^{\text {st }}$ \\
\hline 6 & 60 & 20 & 0 & 0 & 1 & 5 & 2 & 10 & 2 & 10 & 3 & 15 & 1.6 & 1.02 & $1^{\mathrm{st}}$ \\
\hline
\end{tabular}

Table 6: Mortality among Culex quinquefasciatus Larvae treated with different concentrations of Scent leaf extract

\begin{tabular}{|c|c|c|c|c|c|c|c|c|c|c|}
\hline \multirow[b]{2}{*}{$\begin{array}{l}\mathbf{S} / \\
\mathbf{N}\end{array}$} & \multirow{2}{*}{$\begin{array}{l}\operatorname{Concn}(\%) \\
\text { of Scent leaf } \\
\text { extract }\end{array}$} & \multirow{2}{*}{$\begin{array}{l}\text { No of } \\
\text { Larvae }\end{array}$} & \multicolumn{7}{|c|}{ No of mortality/Period of exposure (hr) } & \multirow[b]{2}{*}{ Ranking } \\
\hline & & & $\begin{array}{l}\leq 5 \\
(1)(\%)\end{array}$ & $\begin{array}{l}6-10 \\
(2)(\%)\end{array}$ & $\begin{array}{l}11-15 \\
(3)(\%)\end{array}$ & $\begin{array}{l}16-20 \\
(4)(\%)\end{array}$ & $\begin{array}{l}21-24 \\
(5)(\%)\end{array}$ & Mean & $\begin{array}{l}\text { Std. } \\
\text { Dev. }\end{array}$ & \\
\hline 1 & 10 & 20 & $0(0.0)$ & $0(0.0)$ & $0(0.0)$ & $0(0.0)$ & $0(0.0)$ & 0 & 0 & least \\
\hline 2 & 20 & 20 & $0(0.0)$ & $0(0.0)$ & $0(0.0)$ & $0(0.0)$ & $1(5.0)$ & 0.2 & 0.4 & $4^{\text {th }}$ \\
\hline 3 & 30 & 20 & $0(0.0)$ & $0(0.0)$ & $0(0.0)$ & $0(0.0)$ & $1(5.0)$ & 0.2 & 0.4 & $3^{\text {rd }}$ \\
\hline 4 & 40 & 20 & $0(0.0)$ & $0(0.0)$ & $1(5.0)$ & $2(10.0)$ & $4(20.0)$ & 1.4 & 1.4967 & $2^{\text {nd }}$ \\
\hline 5 & 50 & 20 & $0(0.0)$ & $0(0.0)$ & $1(5.0)$ & $2(10.0)$ & $4(20.0)$ & 1.4 & 1.4967 & $2^{\text {nd }}$ \\
\hline
\end{tabular}


Table 7: Mortality among Culex sp. Larvae treated with different concentrations of G. kola extract

\begin{tabular}{|c|c|c|c|c|c|c|c|c|c|c|}
\hline \multirow[b]{2}{*}{$\mathbf{S} / \mathbf{N}$} & \multirow{2}{*}{$\begin{array}{l}\text { Concn }(\%) \text { of } \\
\text { B.cola } \\
\text { extract }\end{array}$} & \multirow[b]{2}{*}{$\begin{array}{l}\text { No of } \\
\text { Larvae }\end{array}$} & \multicolumn{6}{|c|}{ No of mortality/Period of exposure (hr) } & \multirow[b]{2}{*}{$\begin{array}{l}\text { Std. } \\
\text { Dev. }\end{array}$} & \multirow[b]{2}{*}{ Ranking } \\
\hline & & & $\begin{array}{l}\leq 5 \\
(1)(\%)\end{array}$ & $\begin{array}{l}6-10(2) \\
(\%)\end{array}$ & $\begin{array}{l}11-15 \\
(3)(\%)\end{array}$ & $\begin{array}{l}16-20 \\
(4)(\%)\end{array}$ & $\begin{array}{l}21-24 \\
(5)(\%)\end{array}$ & Mean & & \\
\hline 1 & 10 & 20 & $0(0.0)$ & $0(0.0)$ & $0(0.0)$ & $0(0.0)$ & $0(0.0)$ & 0 & 0 & least \\
\hline 2 & 20 & 20 & $0(0.0)$ & $0(0.0)$ & $0(0.0)$ & $0(0.0)$ & $0(0.0)$ & 0 & 0 & Least \\
\hline 3 & 30 & 20 & $0(0.0)$ & $1(5.0)$ & $2(10.0)$ & $2(10.0)$ & $2(10.0)$ & 1.4 & 0.8 & $2^{\text {nd }}$ \\
\hline 4 & 40 & 20 & $0(0.0)$ & $2(10.0)$ & $2(10.0)$ & $3(15.0)$ & $3(15.0)$ & 2 & 1.095 & $1^{\text {st }}$ \\
\hline 5 & 50 & 20 & $1(5.0)$ & $1(5.0)$ & $1(5.0)$ & $2(10.0)$ & $2(10.0)$ & 1.4 & 0.49 & $2^{\text {nd }}$ \\
\hline 6 & 60 & 20 & $1(5.0)$ & $1(5.0)$ & $2(10.0)$ & $2(10.0)$ & $4(20.0)$ & 2 & 1.095 & $1^{\mathrm{st}}$ \\
\hline
\end{tabular}

Table 8: Mortality among Culex sp. Larvae treated with different concentrations of pawpaw root extract

\begin{tabular}{|c|c|c|c|c|c|c|c|c|c|c|}
\hline \multirow[b]{2}{*}{$\mathbf{S} / \mathbf{N}$} & \multirow{2}{*}{$\begin{array}{l}\text { Concn }(\%) \text { of } \\
\text { pawpaw root } \\
\text { extract }\end{array}$} & \multirow{2}{*}{$\begin{array}{l}\text { No of } \\
\text { Larvae }\end{array}$} & \multicolumn{6}{|c|}{ No of mortality/Period of exposure (hr) } & \multirow[b]{2}{*}{$\begin{array}{l}\text { Std. } \\
\text { Dev. }\end{array}$} & \multirow[b]{2}{*}{$\begin{array}{l}\text { Ran } \\
\text { king }\end{array}$} \\
\hline & & & $\begin{array}{l}\leq 5 \\
(1)(\%)\end{array}$ & $\begin{array}{l}6-10 \\
(2)(\%)\end{array}$ & $\begin{array}{l}11-15 \\
(3)(\%)\end{array}$ & $\begin{array}{l}16-20 \\
(4)(\%)\end{array}$ & $\begin{array}{l}21-24 \\
(5)(\%)\end{array}$ & Mean & & \\
\hline 1 & 10 & 20 & $2(10.0)$ & $2(10.0)$ & $0(0.0)$ & $2(10.0)$ & $2(10.0)$ & 1.6 & 0.8944 & least \\
\hline 2 & 20 & 20 & $2(10.0)$ & $2(10.0)$ & $0(0.0)$ & $4(20.0)$ & $6(30.0)$ & 2.8 & 2.0396 & 5 th \\
\hline 3 & 30 & 20 & $3(15.0)$ & $2(10.0)$ & $2(10.0)$ & $7(35.0)$ & $11(55.0)$ & 5 & 3.5214 & 4 th \\
\hline 4 & 40 & 20 & $3(15.0)$ & $2(10.0)$ & $3(15.0)$ & $8(40.0)$ & $13(65.0)$ & 5.8 & 4.1665 & $3 \mathrm{rd}$ \\
\hline 5 & 50 & 20 & $3(15.0)$ & $2(10.0)$ & $3(15.0)$ & $9(45.0)$ & $15(75.0)$ & 6.4 & 4.9639 & 2nd \\
\hline 6 & 60 & 20 & $7(35.0)$ & $3(15.0)$ & $3(15.0)$ & $14(70.0)$ & $20(100.0)$ & 9.4 & 6.6513 & $1 \mathrm{st}$ \\
\hline
\end{tabular}

\section{Discussion}

It is recognised worldwide that the use of synthetic chemicals for eradication and control of insects are associated with many problems as insects especially mosquitoes develop resistance against chemicals. Therefore, the development of new strategies is important. Bio-pesticides are more useful than chemical because they are less harmful, toxic and cause less environmental pollution. Plant mixtures used against mosquitoes have been found effective (Kumar et al., 2012). A large proportion of these plant extracts have been reported to have mosquitocidal or repellent activities against mosquito vectors. However, few have shown practical utility for mosquito control (Sun et al., 2000). In this present study, it was found that extracts of 6 plants used can be utilized for controlling mosquito larvae. Considerable proportion of plant derivaties have shown to be effective against mosquitoes with a safe manner. The screening of local plants for larvicidal activity may eventually lead to their use in natural product-based mosquito abatement practices. Extracts of plant parts (Annona squamosal, Chrysanthemum indica and Tridax procumbeus) as eco-friendly larvicides have been 
proposed (Kumar et al., 2010). The present findings is addition to the list of plants having larvicidal properties (Gosh et al., 2012; Elkamali 2011; Naraya and Narayanapillai 1996; Kilyanasunduran and Das, 1985).In this study it was found that 60\% concentrations of leaf, roots and seeds of these plant extracts used were most effective against larvae of $C$. quinquefasciatus and showed higher mortality rates of larvae during 21-24hrs. This study has also gain significance because these plants/parts are found to be both effective and perennially available in large quantities or found with ease and at little cost. The study has opened up prospects for large scale extraction of active ingredients of plant origin for effective mosquito control. Also the prominence extends to non-target organism in the ecosystem with little effect by the application of these extracts.

Conclusively, the six plants species tested, all had the potential to be included in the formulation of new and safe control products against $C$. quinquefasciatus. Since these plants are found throughout the country it can help reduce the dependent on expensive synthetic pesticides and stimulate local effort to enhance public health. Further studies on the mode of action, effects on non-target organisms and formulations for improving insecticidal potency is needed for standardization.

\section{Competing Interests}

\section{The authors declare that they have no competing interest.}

\section{Acknowledgement}

Authors thank Zoology Department Board of Post Graduate, Imo State University Owerri for critically examine the manuscript and assessment of progress work. The HODs Agricultural Development Programme (ADP), Plant and Science Laboratory University of Nigeria Nsukka, Phytochemistry Department National Abovirus and Vector Research Center Enugu and Zoology Department, Imo State University Owerri were all acknowledged.

\section{References}

El-Kamali, EI (2001). Larvicidal activity of crude aqueous extract of Solenostemma argel against mosquito larvae. J of herbs, Spices and Medicinal Plants 8(4):83-86.

Gosh, A; Chowdbury N and Chandra G (2012). Plant extrats as potential mosquito larvicides. India J. Med. Res. 135:581-598

Harborne JB (1984). Phytochemical Methods a Guide to Modern Technique of Plant Analysis. 2nd Edn, Chapman and Hall, London, 282-311.

Kalyanasundaram M, Das PK (1985). Larvicidal Synergic Activity of plant Extract for Mosquito Control. Ind J Med Res 19-23.

Kamaraj C, Rahuman AA, Bagavan A, Zahir AA, Elango G, Kandan P (2010). Larvicidal efficacy of medicinal plant extracts against Anopheles stephensi and Culex quinquefasciatus (Diptera: Culicidae) Tropical Biomedicine 27(2):211-219.

Kumar R, Kranthi S, Nitharwal M, Jat S, Monga D (2012). Influence of pesticides and application methods on pest and predatory arthropods associated with cotton. Phytoparasitica. 417-424.

Michaelakis A, Koliopoulos G, Stroggilos A, Bouzas E, Couladouros EA (2009). Larvicidal activity of naturally occurring naphthoquinones and derivatives against the West Nile virus vector Culex pipiens. Parasitol Res 104:657-662.

Mohan DR, Kumar KL (2012). Crude and Partially Purified Leaf Extracts of Tridax Procumbens against the developmental stages of the Mosquitoes, Aedes Aegypti. J Ecotoxicology Environ Monit 22(1):45-48.

Narayan G, Narayanapillai KG (1996). Larvicidal Efficacy of certain plant extracts in mosquito control. Proceedings of the Eighth Kerala Science congress 462-464.

Sun R, Sacalis JN, Chin CK, Still CC (2006). Bioactive aromatic compounds from leaves and stems of Vanilla fragrans. Journal of Agricultural and Food Chemistry 49:51-61.

Sukumar K, Perich MJ, Boobar LR (1991). Botanical derivatives in mosquito control: A review. J Amer Mosquito Control Association. 7:210-237. 
Wattal BL, Joshi GC, Das M (1981). Role of agriculture insecticides in precipitating vector resistance. J Communicable Diseases. 13:71-73. 